\title{
THE EFFECT OF ANTI FRAUD STRATEGY ON FRAUD PREVENTION IN BANKING INDUSTRY
}

\author{
Nurul Alfian \\ Tarjo \\ Bambang Haryadi \\ Faculty of Economics of Trunojoyo University, Madura \\ J1. Raya Telang, Po. Box. 02 Kamal, Bangkalan Madura. \\ fyanque89@yahoo.com; tarjo2005@yahoo.com; haryadilee@yahoo.com
}

\section{ARTICLE INFORMATION}

Article history:

Received August 07, 2016

Revised Dec 10, 2016

Accepted May 19, 2017

\section{JEL Classifications}

D73; K42; G21

\section{Key Words:}

Anti fraud strategic;

Fraud prevention

\section{DOI:}

10.21532/apfj.001.17.02.01.05

\begin{abstract}
The purpose of this study is to examine the effect of anti fraud strategy on fraud preventionin in banking industry. The data are collected through questionnaires distributed to front liners, marketing, and back office. The sampling technique used is proportionale sampling method with 80 respondents. The research data are analysed using quantitative method, particularly explanatory research approach. In this regard, the researchers use Structural Equation Model (SEM) and Partial Least Square (PLS) with Warrpls 5.0 program. The findings of this study show that prevention pillar, detection pillar and investigation pillar have an effect on fraud prevention in banking industry.
\end{abstract}

\section{INTRODUCTION}

\section{Background}

According to the Association of Certified Fraud Examiners (ACFE) fraud is a term that encompasses all forms of irregularities. The scope of the fraud has a very broad scheme, but essentially it involves all actions that violate the trust. The violation will possibly lead to financial losses or even dangerous criminal act. Fraud comes in many shapes and sizes, large and complex, but it can also be small and simple or somewhere in between (Kirk and Woodcock, 1992). Fraud has a very broad scope and encompasses all kinds, such as expense accounts, financial statement irregularities, bid rigging, theft of intellectual property, and others. In addition, the financial 
and service industry sectors, such as banking and insurance, have their own unique types of fraud. The occurrence of fraud at a bank, even though just once, will have a significant impact on the integrity and credibility of the bank, moreover when the fraud is committed by internal party of the bank.

Based on the data held by ACFE, cases of fraud occurred worldwide in 2014. From "The 2014 Report to the Nations on Occupational Fraud and Abuse", it is known that the number of fraud cases have increased every year worldwide causing great losses. Therefore, this fraud must be overcome immediately so that losses incurred from this action can be avoided. The report also shows that the banking sector and financial services sector have the higher level of fraud cases than other sectors. Therefore, the handling of fraud cases should be enhanced, especially in these two areas.

In connection with the actions of fraud in banking industry in Indonesia, the Criminal Investigation Department of Police Headquarters noted that there were cases of crime in the banking sector in 2011, starting from the case of burglary of Bank Rakyat Indonesia (BRI) Cash Office Thamrin Square involving the supervisors of the cash office, assisted by four suspects from outside the bank. The modus was by opening an account in the name of the suspect outside the bank. Money was transferred to the account in the amount of 6 million US dollars. Then the money was exchanged for black dollar (counterfeit US dollar in black) to 60 million US dollars.

From several banking crime cases show that fraud in banking industry often involves internal parties of the bank. The modus is that the crime is committed by an individual together with internal party of the bank, or involving outside parties. $60 \%$ of banking crimes in Indonesia involves internal party of the bank. Based on these realities there are unscrupulous employees of the banks who abuse the authorities given by the company (Kompas, 2014).

Based on the cases, Bank Indonesia (BI), as the central bank of Indonesia, has issued regulation that aims to maintain the stability and credibility of banking institutions. The regulation is the Bank Indonesia Regulation Number: 11/25 / PBI / 2009 on the Implementation of Risk Management for Commercial Banks (PBI Risk Management) and Bank Indonesia Circular Letter (SEBI) No. 13/28 / DPNP dated December 9, 2011 on the application of anti-fraud strategy for commercial banks as one of the rules of the implementation. This regulation basically regulates bank liabilities to always apply the precautionary principle, both in relation to the external parties of the bank and the bank supervision to the internal parties.

The government, through Bank Indonesia, has sought to create a banking climate that is free of fraud. However, based on the facts, fraud occurring in the banking sector, especially BRI bank, is still relatively high, although the central bank has published anti-fraud regulations. Thus, the researchers sought to examine the causes related to how the employee can commit fraud while the central bank has issued regulations 
regarding the prevention of anti-fraud strategy in banking industry.

\section{Formulation of the Problems}

Based on the description stated above, the research questions can be formulated as follows:

1. Does prevention pillar have an effect on fraud prevention measures?

2. Does detection pillar have an effect on fraud prevention measures?

3. Does investigation pillar have an affect on fraud prevention measures?

\section{Research Objectives}

Based on the above formulation, the study aims to test and find out:

1. The effect of prevention pillar on fraud prevention measures

2. The effect of detection pillar on fraud prevention measures

3. The effect of investigation pillar on fraud prevention measures

\section{THEORETICAL BASIS}

\section{Fraud in Banking Sector}

The theory underlying this research is the institutional theory. Institutional theory is a theory that departs from the concepts of sociology that explains the dynamics occurring in an organization that consists of a group of human beings. The main elements of institutional theory are rules, norms, and cultural benefits. Institutional concept also involves association of behavior and material resources.
Fraud is something that is always possible to occur in any financial transaction performed by banking institutions. It is a natural thing when the banking institutions classify fraud as a very terrible economic crime (Hongming and Ling, 2009), especially for the integrity and credibility of the banking institutions that experience such fraud. For institution that relies heavily on the trust of the service users, integrity and credibility are crucial elements that should be maintained in order to continue its intermediary function (Tedi, 2009).

Therefore, the managers of the banks that experience the cases of fraud tend to deal with the cases secretly under the guise of guidance to the institutions. Even sometimes they use a pretext that the problem is occurring in granting credit on bad debtors so that the threat level of fraud against the destruction of the credibility of the organization can be reduced to a minimum. For the sake of the understanding more about the fraud in banking industry, it is necessary to get explanation related to the ins and outs of fraud. Here are the data related to fraud actions based on industry: 
Figure 2.1

Fraud cases based on industry

Figure 22: Industry of Victim Organizations

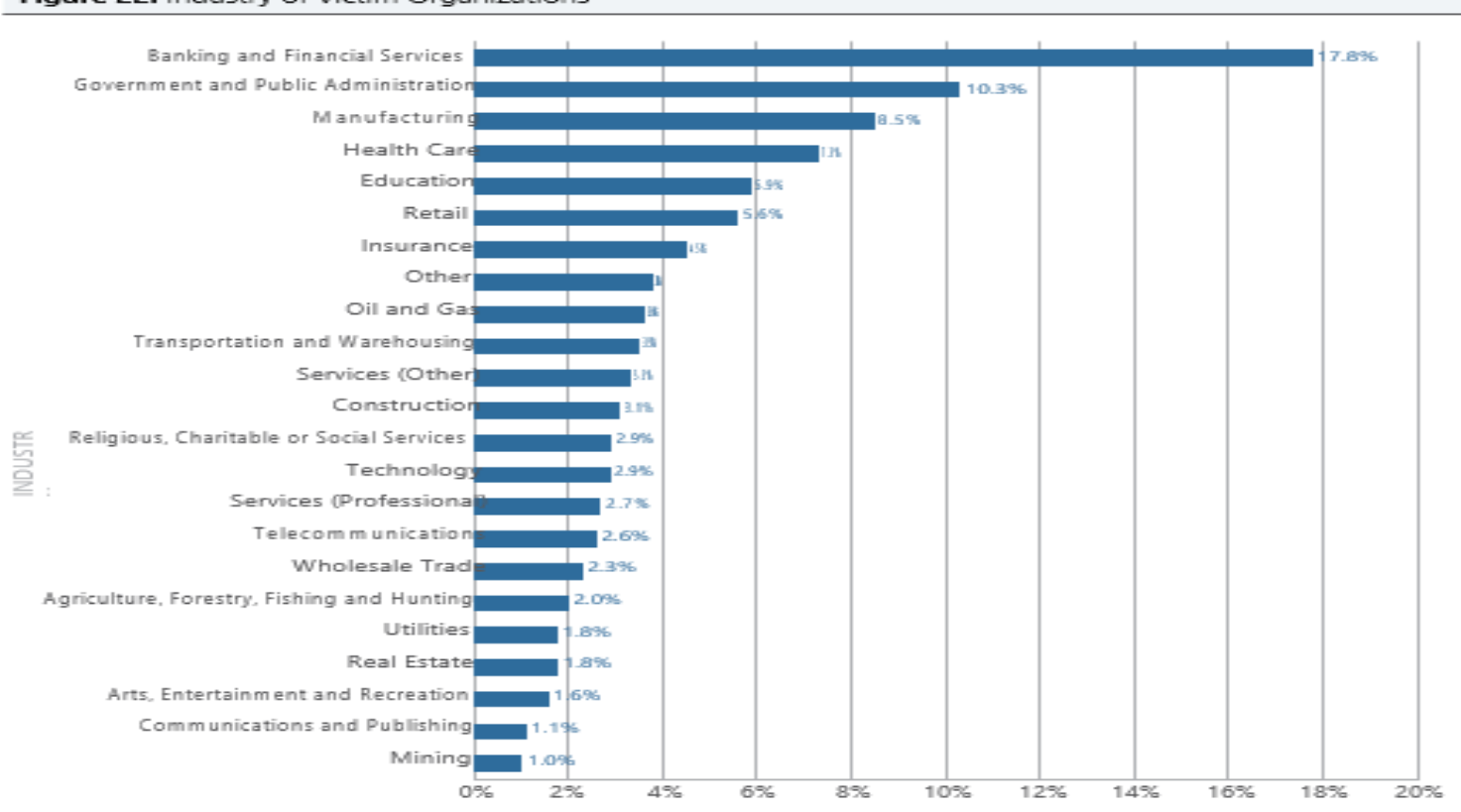

Source: The 2014 Report to the Nations on Occupational Fraud and Abuse

From the figure above, it can be seen the addition of fraud cases every year worldwide that have caused great losses. Therefore, this fraud action must be overcome so that losses incurred from such a crime can be avoided. From the figure above, it can also be seen that the banking sector and financial service sector have higher rate of fraud cases than other sectors of industry. Therefore, the handling of fraud cases should be enhanced.

Judging from the above conditions, the banking industry in Indonesia, in fact, also has a high level of concern in the cases of fraud. The concern is expressed in the form of a new provision made by Bank Indonesia. The new provision of the central bank is on anti-fraud policy that contains an obligation of banks to own and implement anti-fraud strategy adapted to the internal and external environment, the complexity of business activities, potential, types, and the risk of fraud and supported by adequate resources.

Anti-fraud strategy is part of a strategic policy in which the implementation is realized in fraud control system. For the banks that already have anti-fraud strategy but still do not meet the minimum benchmark, shall adjust and enhance the anti-fraud strategy that has been owned and shall submit the monitoring report of the implementation of anti-fraud strategy to BI as the Central Bank. To control the risk of fraud, the banks need to implement risk management by strengthening some aspects that at least include Active Supervision of Management, Organizational Structure and Accountability, as well as Control and Monitoring.

Related to this, Bank Indonesia has issued Circular regarding Anti-Fraud Strategy Implementation for Commercial Banks as an effort to prevent cases of fraud in banking 
industry that is detrimental to customers. This Circular is expected to encourage commercial banks to better prevent fraud. This arrangement serves as a tool to strengthen the Bank's internal control system as well as the further implementation of Bank Indonesia Regulation (PBI) No. 5/8 / PBI / 2003 dated May 19, 2003 concerning the implementation of Risk Management in Commercial Banks. This arrangement is expected to steer the bank in controlling fraud through efforts which do not only to prevention, but also to detect and to investigate as well as to improve the system as part of an integrated strategy in controlling fraud.

\section{Anti-Fraud Policy: Anti-Fraud Strategy}

In preparing a new regulation, there must be purposes and objectives to be achieved by the maker. In addition, there must also be something urgent underlying the creation of a new regulation, such as the anti-fraud strategy which was successfully issued by Bank Indonesia on 9 December 2011. There are several reasons for Bank Indonesia to issue anti-fraud strategy that specifically and explicitly regulate what commercial banks in Indonesia should do to prevent fraud. Here are some factors underlying the preparation of anti-fraud strategy:

1. As a means of strengthening the bank's internal control system and as the further implementation of Bank Indonesia Regulation No. 5/8/2003 dated May 19, 2003 concerning the Application of Risk Management for Commercial Banks;
2. Due to the disclosure of the various cases of fraud in the banking sector that are detrimental to the customers, it is necessary for the banks to regulate provisions concerning the implementation of anti-fraud strategy

3. As an effort to increase the effectiveness of internal control considering the disclosure of in view of various cases of fraud in banking sector in Indonesia;

4. As a means to make fraud prevention become the focus of attention and culture in all aspects of the organization in any commercial bank in Indonesia;

5. As a means to give a proper and thorough understanding of fraud to management at all commercial banks in Indonesia; and

6. As a guideline in controlling fraud through efforts that not only for prevention, but also for detection, investigation and improvement of the system as part of an integrated strategy in controlling fraud

In connection with the above underlying factors, with many cases of fraud revealed in banking sector in Indonesia, Bank Indonesia followed up by conducting research and surveys before finally making regulations regarding anti-fraud strategy. One of the results of the survey that become the basis for Bank Indonesia to examine more deeply about the fraud in banking industry is the survey of the ACFE in 2010, which states:

1. The survey was conducted on 1,843 cases of fraud in the period from January 2008 to December 2009 from 1,006 countries in the world; 
2. The biggest loss experienced by a bank is generally caused by fraud, which is estimated reaching up to $5 \%$ of total annual revenue;

3. Fraud is difficult to detect, especially that involving executive level. Most take 18 months to finally be detected;

4. $85 \%$ of fraud perpetrators have never been involved in such crimes or other crimes;

5. $80 \%$ of fraud cases occur at the divisions of accounting, operations, marketing, executives, customer service and purchasing;

6. $20 \%$ of banks that experience fraud do no make improvement of internal controls after the occurrence of fraud; and

Fraud perpetrators show the signal that they are involved in fraud, among others, through the changes in the lifestyle beyond reasonableness $(43 \%)$ or the financial difficulties they experience.

\section{Prevention Pillar}

Fraud prevention can be done by building a good internal control structure, streamlining control activity, improving organizational culture and streamlining the functions of internal audit (Amrizal, 2004). COSO (1992) confirms that the goal of prevention is to be able to provide adequate confidence in achieving three main objectives; the reliability of financial reporting, the effectiveness and efficiency of operations, and the compliance with applicable laws and regulation.

Tuanakotta (2007: 162) reveals that fraud prevention can be done by activating the internal control. An active internal control is usually a form of internal control most widely implemented in institutions.

Cuomo(2007) states that the implementation of internal controls, in the profit or non-profit company, can protect company assets from fraud and can certainly assist management in carrying out all its activities. The construction and implementation of internal control are expected to be part of fraud prevention. In addition, it is expected to lead to deterrence against fraud committed by internal and external parties. So, the hypothesis can be formulated as follows:

H1: prevention pillar has an effect on fraud prevention

\section{Detection Pillar}

Fraud detection is a key responsibility of management (Coram et al., 2001). The management of an entity, including banks, should be able to build a good system that can detect such fraud. If fraud can be detected early, the bank can avoid greater losses. Mark Zimbelman (2006: 114), a good whistleblowing program can be a very effective tool in detecting and preventing fraud.

In reducing the occurrence of fraud, it is necessary to carry out the detection of fraud, in this case, by using the mechanism of whistleblowing system. This is in line with the research conducted by Irvandly (2014) concerning the effect of the application of the whistle-blowing system on the fraud detection. From the results of the research conducted by Irvandly show that the application of the whistle-blowing system 
has a significant effect in reducing fraud. Meanwhile, the magnitude of the effect of the application of the whistle-blowing system in contributing to the prevention of fraud is $16.3 \%$. So, the better the implementation of the whistle-blowing system in the company, the higher the level of disclosure of fraud cases.

According to Arens (2008), many companies or organizations have implemented a whistle-blowing mechanism for employees to report actual or suspected violation or potential violation on codes of conduct or ethics policy. This mechanism is one way to create a positive work environment. Positive work environment can be a supportive measure in preventing fraud in a company. Therefore, the hypothesis can be formulated as follows:

H2: Prevention pillar has an effect on fraud prevention

\section{Investigation Pillar}

Investigative audit is a systematic and measured activity to uncover fraud since it is known or there is an indication of an event or transaction that may provide sufficient confidence and can be used as evidence that meets the ascertainment of a truth in describing the event that has previously been assumed in order to achieve justice (Pusdiklatwas, 2008).

The results of the research conducted by Ewi (2014) at the Financial and Development Supervisory Agency (hereinafter referred to as BPKP), West Java province representative and involved investigative auditors as respondents or sample show that the hypothesis is accepted, in which the ability of an investigative auditor has a significant effect on the effectiveness of audit procedures in the proof of fraud.

Zulaiha (2008) conducted a study of the effect of the investigative auditor's ability on the effectiveness of the implementation of audit procedures in the proof of fraud, with a sample of the Supreme Audit Board (hereinafter referred as BPK) West Java representative. The study reveals that the investigative auditor's ability has an effect on the effectiveness of the implementation of audit procedures in the proof of fraud. Then the hypothesis can be formulated as follows:

H3: Investigation pillar has an effect on fraud prevention

\section{RESEARCH METHOD}

This study uses a quantitative method with explanatory research approach. The population in this study is the parties involved in the operational activities in banking of Pamekasan branch office. The sampling is conducted using purposive sampling method. The data used in this study are primary data obtained from questionnaires.

The independent variables in this study are prevention pillar, detection pillar, and investigation pillar, while the dependent variable is fraud prevention. The measurement scale used to test the instrument is a Likert scale of 1 to 5 points. 


\section{Framework}

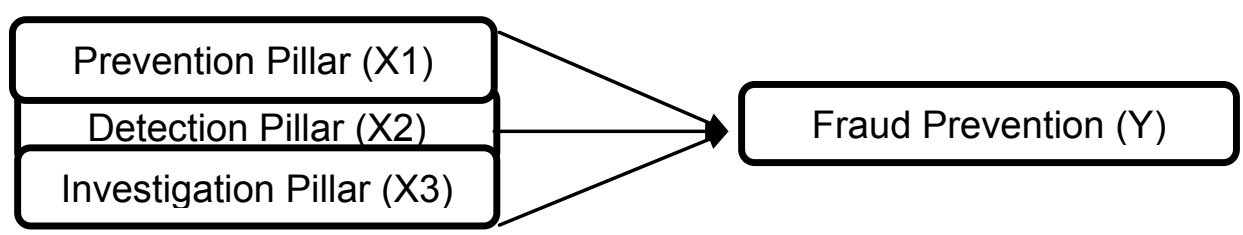

\section{Data Analysis}

The hypothesis test in this study is conducted using Partial Least Square (PLS). PLS is an alternative method of analysis with Structural Equation Modelling (SEM) based on variance. The program used to test the hypothesis is Warppls 3.0. There are some steps to test the hypothesis using PLS method, among others are;

1. Evaluation of the measurement model or outer model;

2. Evaluation of the structural model or inner model;

3. Hypothesis test (resampling blinfolding).

\section{REESEARH RSULTS}

The number of questionnaires distributed in the study is 80 questionnaires. The number of returned questionnaires is 62 questionnaires. So, there are 18 questionnaires which are not returned. The response rate is high, or $75 \%$. Of the 62 questionnaires returned, there are two incomplete questionnaires that are excluded from the sample. So the number of samples analyzed is 60 questionnaires.

\section{Evaluation of Measurement Model or Outer Model}

The validity test results using PLS technique with Warppls 5.0 program explain that the variables of prevention pillar, detection pillar, investigation pillar, and fraud prevention have met the criteria in which the loading values are above 0.40 with $p$-value $<0.05$. Moreover, the value of average variance extracted (AVE) is above 0.50 .

Reliability test is measured using composite reliabiliy and cronbach alpha. Both components must have a value above 0.70 as a requirement of reliability. The value of Composite reliability coefficients of each construct has met the requirement, or above 0.70. In addition, the value of Cronbach's alpha coefficients of each construct has also met the reliability requirement as proposed by (Fornell and Lacker, 1981; Nunnaly 1978 in Solihin and Ratmono, 2013).

\section{Evaluation of Structural Model or Inner Model}

Based on the analysis results of Partial Least Square to test the structural model (inner model) with Warppls 5.0 Program, the value of R-Squared is 0.625 . The test results can be interpreted that the variables of prevention pillar, detection pillar, and investigation pillar are able to explain $62.50 \%$ of fraud prevention, while the remaining $37.50 \%$ is influenced by other factors that are not included in this model. 
Q-squared aims to measure how well the predictions generated by the model of the constructs. Based on calculations, it can be seen that the value of Q-squared is 0.637 . This shows that the model in this study has predictive relevance because the value of Q-squared $>0$. The exogenous variables such as prevention pillar, detection pillar, and investigation pillar have predictive relevance with the variable of fraud prevention.

\section{DISCUSSION}

Prevention pillar has an effect on fraud prevention. In this study, prevention pillar has a significant effect on fraud prevention efforts because prevention pillar, ie internal control system, is the policies and procedures designed by the management to provide feasible assurance that the company has achieved its goals and objectives. This means that prevention pillar has a great influence on the sustainability of the company using the internal control systems that include control environment, risk assessment, control standards, information, communication, and monitoring. Thus, the company can carry out all its activities in accordance with the objectives and targets to be achieved.

If this is associated with institutional theory, the adherence to the rules, norms and procedures describes the conditions inside the institution. The implementation of strong internal control system will reduce the opportunity of the respondents to commit fraud.

Despite the differences in internal control applied to any organization, the internal control is basically put in place with the same goal, that is, to protect the company's assets. It is supported by same research conducted by Kusumastuti (2012) that the internal control has an effect on fraud. The companies that implement internal control would help them check the occurrence of fraud easily, and ultimately it will be easy to detect fraud at an early stage.

This study shows that detection pillar has a significant effect on fraud prevention efforts because detection pillar, ie whistle-blowing system, is a system that can create positive work environment, and the fraudsters will think over and over whether they would continue to commit fraud or cancel it. They are afraid if what they committed and what they will commit will be reported by the whistleblower. Otherwise, if there is no participation from whistleblower, the fraud would be easily committed let alone the control system and supervision of the organization is in bad condition, coupled with the absence of clear and strong legal protection to the whistleblowers. Such condition may cause people afraid to report indications of fraud which they discover and choose to keep silent in order to be free from any risk.

The opinion is also in line with the opinion expressed by Albrecht (2009: 118) that a good whistle-blowing system is one of the best tools that function as fraud prevention measures. When an employee understands that other employees have a simple way to monitor each other and can report the allegations of fraud, the employees will have no intention to get involved in fraud action.

In this study, investigation pillar has a significant effect on fraud prevention 
efforts because investigation pillar, ie audit investigation consisting of stages of initial information review, investigative audits planning, implementation of investigative audits and investigative audit reporting, plays an important role in monitoring activities suspected of fraud and to ensure that antifraud programs and controls are effective. So, the implementation of a strong investigation pillar will facilitate the investigation auditor in conducting proof of fraud. If this is attributed to institutional theory that institution is a social system boundaries covered by formal and nonformal rules as the controller and director of human interaction in access to resources, the compliance with the rules will describe the conditions of the investigation process carried out by the auditor, as a sign of whether there is fraud or not.

The results of the research conducted by Ewi (2014) at the Financial and Development Supervisory Agency, West Java province representative and involved investigative auditors as respondents or sample show that the hypothesis is accepted in which the ability of investigative auditor has a significant effect on the effectiveness of audit procedures in the proof of fraud.

\section{CONCLUSION AND SUGGESTION \\ Conclusion}

Based on the analysis and discussion, it can be concluded that the testing which is conducted simultaneously using re-sampling blindfolding shows that prevention pillar, detection pillar, and investigation pillar have a significant influence on fraud prevention measures. This means that the strong implementation of prevention pillar, detection pillar, and investigation pillar in the anti-fraud strategy will increase fraud prevention efforts in the banking world.

\section{LIMITATION}

The limitations of this study are as follows:

1. Data collection technique is conducted using questionnaires so that there is no direct interaction with the respondents.

2. This study has not tested pillar of followup.

3. The research object is only focused on one bank.

\section{SUGGESTION}

Based on the research results, it is expected that; 1) the results of this research serve as a consideration for the regions and the center to further strengthen the position of internal control system in accordance with Bank Indonesia Circular Letter (SE BI), so as to reduce and prevent the occurrence of fraud in banking industry; 2) the results of this research serve as a reference for the decision makers and branch managers to continue to maintain and improve the competence of internal auditors through the provision of training and the opportunity to follow courses or enhancement of education, especially in handling audit fraud.

Based on the limitations described above, it is suggested that future studies include direct interviews or face to face to collect research data in order to reduce the weaknesses related to internal validity, add variables that have not 
been tested in the research related to anti-fraud strategy, and expand the research object on all banks within the region of East Java so that the results can be generalized.

\section{REFERENCES}

Abiola, Idowu \& Adedokun Taiwon Oyewole. 2013. Internal Control System on Fraud Detection : Nigeria. Journal of Accounting and Finance Vol. 13 (5) 2013 Albrecht etal. 2009. Fraud Examination, third edition, south western, a part of chengange learning. USA.

Amrizal. 2004. Pencegahan dan Pendeteksian Kecurangan oleh Internal Auditor. www. bpk.go.id/ Diakses 16 Februari 2015.

Arens, Alvin.A. 2008. Auditing Dan Jasa Assurance Pendekatan Terintegrasi Jilid I. Erlangga: Jakarta.

Association of Certified Fraud Examiner. 2014. Report to the Nation on Occupational Fraud and Abuse. USA: Global Fraud Study.

Banjarnahor, Ewi. 2014. Pengaruh Penerapan Akuntansi Forensik dan Audit Investigatif Terhadap Pengungkapan Fraud Kasus Korupsi. Universitas Mercubuana. Jakarta.

Burnaby et.al. 2011. Detecting Fraud in The Organization: An Internal Audit Perspective. Journal of Forensic \& Investigative Accounting . Vol. 3

COSO.1992. Coso Internal Control. Integritas Framework. Diakses 19
Februari 2013 dari COS (Committe of Sponsoring Organizations of the Treadway Commisions).http://www. coso.org/document/internal\%20 controlintegrated $\%$ framework.pdf.

Coram, P., Leung, P., Gill, G. S. \& Cosserat, G. 2001. Modern Auditing and Assurance Services. Milton: John Wiley and Sons.

Cuomo, A. M. 2007. International ControlIntegrated Framework, Committee of Sponsoring Organizations of The Tread Way Commission.

Ghozali, Imam. 2006. Structural Equation Modeling Metode Alternatif Dengan Partial Least Square. Badan Penerbit Universitas Diponegoro. Semarang.

Ghozali, Imam. 2007. Aplikasi Analisis Multivariate dengan program SPSS. Semarang: Badan Penerbit Universitas Diponegoro.

Gusnardi. 2008. Pengaruh Peran Komite Audit, Internal Control dan Internal Audit Dalam Pelaksanaan Good Corporate Governance dan Pencegaha Fraud. Disertasi Bandung: Program Pascasarjana. Universitas Padjajaran.

Hongming Cheng, dan Ling Ma, 2009. Journal of Financial Crime Emerald Article: White Collar Crime and The Criminal Justice System: Government Resonse to Bank Fraud and Corruption in China. Vol. 16 Iss: 2 pp. 166-179

http://bisniskeuangankompas.com/2014. report-to-nations.pdf. diakses 18 maret $\underline{2014}$ 
Indriantoro, Nur., Bambang Supomo, 2009. Metodologi Penelitian Bisnis untuk Akuntansi dan Manajemen, Edisi Pertama. Yogyakarta : BPFE Yogyakarta.

Iqbal, Muhammad. 2010. Pengaruh Tindakan Pencegahan, Pendeteksian dan Audit Investigatif terhadap Upaya Meminimalisir Kecurangan Dalam Laporan Keuangan. Tesis. Universitas Islam Negeri Syarif Hidayatullah Jakarta. Irvandly, Pratama Libramawan. 2014. Pengaruh Penerapan Whistleblowing System Terhadap Pencegahan Kecurangan. Skripsi. Univesitas Widyatama.

Kirk, DN \& Woodcock, AJJ. 1992. Serious Fraud: Investigation and Trial. Butterworths.

KNKG, 2008. Pedoman Umum Good Corporate Governance Indonesia

Konsorsium Organisasi Profesi Audit Internal, 2004, Standar Profesi Audit Internal, Jakarta.

KPMG Forensic. 2010. Fraud and Misconduct Survey. Australia and New Zealand

Kusumastuti, Nur Ratri. 2012. Analisis Faktorfaktor yang Berpengaruh terhadap Kecenderungan terhadap Kecenderungan Kecurangan Akuntansi dan Perilaku Tidak Etis sebagai Variabel Intervening”. Skripsi: Semarang. UNDIP.

Pusdiklatwas BPKP. 2008. Fraud Auditing. Makalah Disajikan dalam Diklat Penjenjangan Auditor Tim. Bogor, Desember.
Rustendi, Tedi. 2009. Analisis Terhadap Faktor Pemicu Terjadinya Fraud: Suatu Kajian Teoritis Bagi Kepentingan Audit Internal. Jurnal Akuntansi Vo. 4 No. 2. Jakarta

Solihin, Mahfud dan Ratmono, Dwi. 2013. Analisis SEM-PLS dengan WarpPLS 3.0. Yogyakarta: Andi Yogyakarta.

Surat Edaran Nomor 13/28/DPPNP. Perihal Penerapan Strategi Anti Fraud bagi Bank umum.

Zimbelman, Market at. 2006. Fraud Examination, 3 rd Edition. Mason: SouthWestern Cengage Learning. 